\title{
A HAJDÚ-BIHAR MEGYEI SZÁNTÓFÖLDI NÖVÉNYTERMESZTÉSSEL FOGLALKOZÓ TÁRSAS VÁLLALKOZÁSOK JÖVEDELMEZŐSÉGÉNEK MEGÍTÉLÉSE KÜLÖNÖS TEKINTETTEL A HAJDÚBÖSZÖRMÉNYI GAZDÁLKODÓKRA
}

THE PROFITABILITY ANALYSES OF CROP PRODUCTION ENTERPRISES IN HAJDÚ-BIHAR COUNTY, ESPECIALLY IN HAJDÚBÖSZÖRMÉNY

\author{
Erdős Adél Dorottya ${ }^{1}$, Szőllősi László ${ }^{2}$ \\ ${ }^{1} \mathrm{PhD}$ hallgató, ${ }^{2}$ egyetemi docens \\ ${ }^{1}$ Debreceni Egyetem, Gazdaságtudományi Kar, Ihrig Károly Gazdálkodás- és \\ Szervezéstudományok Doktori Iskola \\ ${ }^{2}$ Debreceni Egyetem, Gazdaságtudományi Kar, Gazdálkodástudományi Intézet, Üzemtani és \\ Vállalati Tervezés Tanszék \\ E-mail: erdos.adel.dorottya@econ.unideb.hu ${ }^{1}$, szollosi.laszlo@econ.unideb.hu²
}

\section{Összefoglalás}

Magyarországon a mezőgazdaság az alapanyagtermelés tekintetében kimagasló szereppel bír. $\mathrm{Az}$ agráriumon belül a legnagyobb arányt képviselő növénytermesztési ágazatot a támogatáspolitika is kiemelten kezeli. Hazánkban számos olyan megye található, ahol kimagasló feltételek (jó talajminőség, kedvező időjárási körülmények, magas aranykorona értékủ szántó) állnak rendelkezésre a növénytermelésre. Az egyik legjelentősebb megyének Hajdú-Bihar tekinthető, ahol 325 ezer hektár szántóterület található. A hajdúböszörményi vállalkozások e terület mintegy $8 \%$-át használják. Kutatómunkánk során szekunder adatokat dolgoztunk fel a KSH (agráriumot jellemző országos és megyei adatok) és az EMIS adatbázisából (társas vállalkozások beszámolóinak adatai). A vizsgált 853 magyarországi vállalkozáson belül különös figyelmet fordítottunk a Hajdú-Bihar megyei és hajdúböszörményi gazdaságokra. A müködési ROS, ROE és a ROI értékei alapján megállapítottuk, hogy mind a megyei, mind a hajdúböszörményi üzemek jövedelmezően termeltek, viszont eltérő üzemmérettel rendelkeztek. A hajdúböszörményi társas vállalkozások a müködési ROS tekintetében $(12,57 \%)$ kedvezőbb helyzetben voltak az országos $(5,30 \%)$ és a megyei $(8,90 \%)$ átlagértékekhez viszonyítva. Mindez a magasabb befektetett eszközértékkel és -aránnyal magyarázható a 2015-2019-es idöszakra vonatkozóan. E mögött korszerübb technológia feltételezhetö.

\begin{abstract}
In Hungary agriculture has a prominent role in terms of raw material production. Crop production representing the highest proportion of it and support policy prioritizes it also. In our country there are many counties, where outstanding conditions (good soil quality, favourable weather conditions, arable land with a high golden crown value) are for producing crop. One of the most significant county is Hajdú-Bihar, where 325 thousand hectares arable land are. 8 percent of this area is used by enterprises in Hajdúböszörmény. During our research secondary data were used from HCSO (national and county data specific to agriculture) and EMIS database (report details of enterprises). In the examined 853 Hungarian enterprises farms of Hajdú-Bihar County and of Hajdúböszörmény were payed special attention. Based on value of operating ROS, ROE and ROI both farms of county and Hajdúböszörmény produce profitable, however their farm size were different. The enterprises in Hajdúböszörmény had favourable situation based on operating ROS $(12,57 \%)$ compared to national $(5,30 \%)$ and county $(8,90 \%)$
\end{abstract}


average values. All of this can be explained by the higher fixed assets value and rate for the period 2015-2019. Behind this more advanced technology are presumed.

Kulcsszavak: szántóföldi növénytermesztés, társas vállalkozások, jövedelmezöség, EMIS adatbázis

JEL besorolás: $M 11, Q 12$

LCC: S560-571.5

\section{Bevezetés}

A magyar mezőgazdaság részaránya a bruttó hozzáadott értéken belül 3,6\%-ról 4,1\%-ra változott 2009 és 2019 között. A szántóföldi növénytermesztés az agrárium meghatározó részét jelenti, ugyanis az agrárium teljes kibocsátási értékének döntő részét (57\%) ez adja (KSH, 2020a). Szabó (2019) arra hívta fel a figyelmet, hogy a növénytermesztés az állattenyésztésnél nagyobb mértékben támogatott, ugyanis a SAPS a gabonafélék és az ipari növények termelését helyezte előtérbe, szemben az állati termékek előállításával. Így ezen vállalkozások számára a nagyobb jövedelem elérését a kevesebb foglalkoztatotti létszám (gépesítettség) is biztosította (Szabó, 2019).

Napjainkban a mezőgazdasági vállalkozások egyik kulcsfontosságú témájává a versenyképes termelés megvalósítása vált. Szőllősi - Molnár (2017) szerint ahhoz, hogy ez létrejöhessen egy adott gazdaság tekintetében, üzemi szinten hatékonynak és jövedelmezőnek kell lennie. Ebből kifolyólag e két tényező a versenyképesség befolyásoló tényezőinek tekintendő. A hatékonyság fogalmát Nábrádi et al. (2008) a következőképpen definiálta: „Gazdasági értelemben a hatékonyság a gazdálkodás eredményességének kifejeződése.”

A hazánkban mintegy 4,3 millió hektáron gazdálkodó szervezetek meghatározó szerepet töltenek be az alapanyag-előállítás tekintetében. Ezen belül kiemelendők a Hajdú-Bihar megyei társas vállalkozások, amelyek országos viszonylatban is kimagasló minőségű szántófölden termelnek. Ezenkívül ebben a térségben az időjárási körülmények is kedvező feltételeket teremt a magasabb hozamok eléréséhez. E megyén belül a hajdúböszörményi gazdálkodók a megyei szántóterület mintegy 8\%-án (25 ezer hektáron) végezik tevékenységüket (TAKARNET, 2020). Ebből kifolyólag esett a választás a Hajdúböszörményben fötevékenységként gabonaféle (kivéve: rizs), hüvelyes növény, olajos mag termesztéssel foglalkozó társas vállalkozások jövedelmezőségének vizsgálatára országos, illetve Hajdú-Bihar megyei viszonylatban. Fenyves et al. (2020) hasonló jellegü kutatást végzett a V4 országaira vonatkozóan és arra a megállapításra jutottak - beleértve a magyarországi üzemeket is -, hogy a jövedelmezőbb vállalkozások általánosságban véve tőkeerősebbek, így adósság-problémájuk kevésbé adódik.

A tanulmány célkitüzése a hajdúböszörményi szántóföldi növénytermesztéssel foglalkozó társas vállalkozások jövedelmezőségének vizsgálata országos és megyei adatok függvényében.

\section{Anyag és módszertan}

A kutatómunkánk során szekunder adatokat gyüjtöttünk a KSH és az EMIS adatbázisokat felhasználva. A KSH adatbázisából feldolgoztuk a mezőgazdaságra jellemző Hajdú-Bihar megyei és országos adatokat (pl. termésátlagok, felvásárlási és ráfordítási árszínvonalváltozások, agrárolló tekintetében). A nemzetközi EMIS adatbázisból a szántóföldi növénytermesztéssel, ezen belül a TEÁOR szerint gabonaféle (kivéve: rizs), hüvelyes növény, olajos mag termesztéssel (főtevékenységként) foglalkozó magyarországi vállalkozások közzétett beszámolóinak adatait használtuk fel. A feldolgozás során csak azokat a cégeket 
vettük figyelembe, amelyek a 2015-2019-es időszak során hiánytalanul rendelkeztek adatokkal. Mindemellett kutatásunk során több szempont szerint is szürtük az adatbázist: legalább 20\%os befektetett eszközaránnyal kellett rendelkezniük, illetve ezzel együtt a kiugró értékeket is kiszürtük. A vizsgált minta elemszáma a szürést követően 853. A rendelkezésre álló EMIS adatokhoz hozzárendeltük külön adatbázisokból a székhelyet és így megyei bontásba osztottuk szét a vállalkozásokat. Ezen belül különös figyelmet fordítottunk a Hajdú-Bihar megyei és a hajdúböszörményi vállalkozások jövedelmezőségének vizsgálatára. Hajdú-Bihar megyei gazdaságok száma 69, ezen belül 4 hajdúböszörményi üzem található meg. Utóbbi cégek teljesítményét elhelyeztük országos és megyei összehasonlításban is. A begyüjtött adatokat leíró statisztikai módszerekkel (átlag, szórás, relatív szórás, minimum és maximum értékek, osztályközös gyakoriság) dolgoztuk fel. Ezenkívül korreláció-elemzéssel megvizsgáltuk, hogy a kalkulált hatékonysági mutatók a mérlegföösszeggel, valamint az értékesítés nettó árbevétellel milyen kapcsolatot mutat.

A jövedelmezőségi mutatók számítása során a müködésre helyeztük a hangsúlyt, azaz az üzemi üzleti tevékenységet határoztuk meg eredménykategóriaként. A kalkulált jövedelmezöségi mutatók a következők: árbevétel arányos üzemi eredmény (müködési ROS), saját tőke müködési hozama (ROE) és befektetett eszközarányos jövedelmezőség (ROI). Bareith et al. (2014) és Fenyves et al. (2019) alapján alkalmaztuk a müködési ROS-t, amely megmutatja, hogy egységnyi árbevételre mekkora üzemi eredmény jut. A ROE mutatót Pechrova (2015) és Fenyves et al. (2019) is jelentős pénzügyi mutatóként használta, amely kifejezi, hogy egységnyi saját tőkével mekkora üzemi eredmény érhető el. A befektetett eszközarányos jövedelmezőség a befektetett eszközök jövedelemtermelö-képességét fejezi ki (Szöllösi - Szücs, 2015).

A vállalkozások ROE mutatóinak értékelése során tovább szükítettük a mintát, kizárva azokat a cégeket, amelyek negatív saját tőke értékkel rendelkeztek, mivel esetükben a ROE mutató torzítást mutat veszteséges müködés mellett. Ez a kizárás 9 vállalkozást érintett, amelyből egy Hajdú-Bihar megyei. Így a szektor vállalkozásainak saját tőke arányos jövedelmezőségének megítéléséhez felhasznált minta elemszáma 844 volt, ebböl a Hajdú-Bihar megyei cégek száma 68.

\section{Eredmények}

\section{A jövedelemtermelö-képességet befolyásoló tényezök}

A mezőgazdasági vállalkozások esetében különösen figyelembe kell venni azokat a tényezőket, amelyek a jövedelemtermelö-képességet kedvező irányba befolyásolják, mert a független tényezők (pl. időjárási viszontagságok: aszály, jégeső) így is jelentős hatást tudnak gyakorolni. Alapvetően azt az elvet szükséges követni, hogy a ráfordításokat olyan mértékben növeljük (termelési költség növelése), hogy a bevételek ennek eredményeképpen is nagyobb arányban növekedjenek. Így a többlet ráfordítások hatékonyságára helyezzük a hangsúlyt. Amíg a termelési költségre döntően felhasznált ráfordítások mennyisége és azok árai, addig a termelési értékre többnyire a termésmennyiség és a felvásárlási árak hatnak. Utóbbi értékét a támogatások is befolyásolják. (Apáti et al., 2018b). Ebben az alfejezetben az egyes termények felvásárlási árindexének és a föbb ráfordítások árszínvonalának alakulása mellett, a termésátlagok megyei és országos átlagértékét, valamint a szántóföldek piaci árát befolyásoló tényezőit is vizsgáljuk.

A gabonafélék és ipari növények termelöi árszínvonalának változását az 1. ábra szemlélteti. Megfigyelhető, hogy a gabonafélék értékesítési árai 2016-ban, míg az ipari növények felvásárlási árai 2018-ban növekedtek az előző évhez viszonyítva a legnagyobb mértékben. 2017-ben mind a gabonafélék, mind az ipari növények termelői árai csökkentek. 


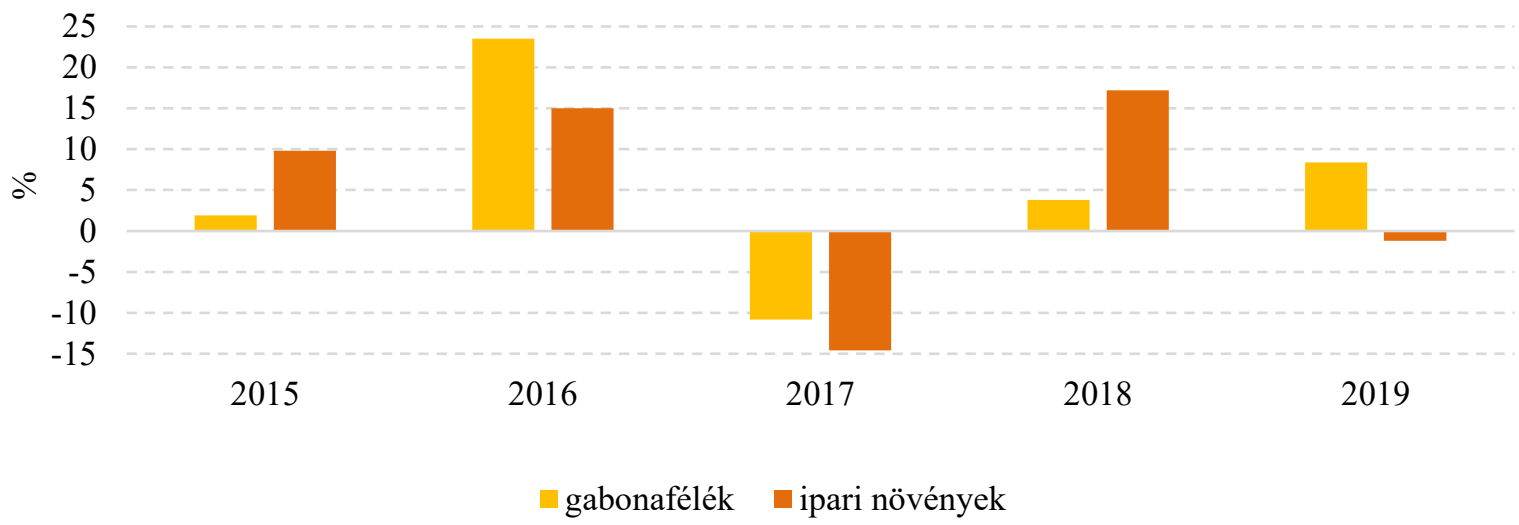

1. ábra: A gabonafélék és ipari növények termelői árindexe (előző év=100\%) Forrás: KSH, $2020 b$

Ami a ráfordítások árait illeti, a legnagyobb mértékben a vetőmagok árai növekedtek a vizsgált időszak alatt. 2015-ben 9,5\%-kal, majd 2018-ban 5,9\%-kal emelkedtek. Ennek hátterében a forint árfolyamának változásai állhattak, amely az importtermékek árát megnövelte. A következő kiemelendő ráfordítás az energia, amelyek árai 2017-ben 5,7\%-kal, majd 2018-ban 7,4\%-kal növekedtek. A harmadik jelentős ráfordítástétel a növénytermesztési ágazatban a mütrágya. A KSH (2020b) adatai szerint, amíg 2015-ről 2016-ra átlagosan 11\%-kal és 2016ról 2017-re 7\%-kal csökkent a mütrágya ára, addig 2018-ban 3,8\%-kal, 2019-ben pedig 7,9\%kal lettek magasabbak az elóző évekhez viszonyítva. Utóbbi hátterében a szakértők nagymértékben befolyásoló tényezőnek tartották a földgáz árának növekedését, amely főleg a nitrogénmütrágyák áralakulását befolyásolta. A foszfor- és káliummütrágyák áraira többnyire a kőolaj és villamos energia árak hatottak. Az energiaárak átlagosan 6-8\%-kal növekedtek 2017-2018 között. Ezenkívül kiemelendő tényezők még a forint árfolyamának alakulása, a termékek iránti kereslet növekedése, továbbá a szállítási körülmények is (Apáti et al., 2018a) (2. ábra).

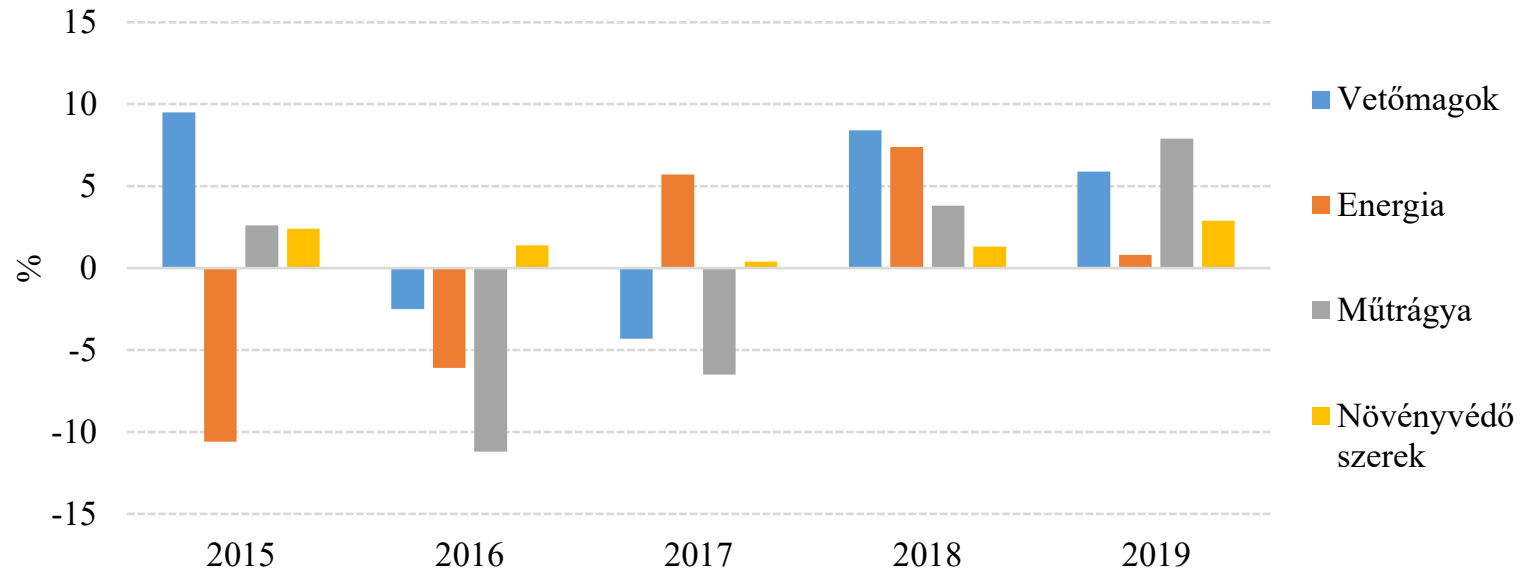

2. ábra: A főbb ráfordítások árindexei (előző év=100\%)

Forrás: KSH, $2020 b$

A termelöi és ráfordítási árindexek alapján meghatározhatóvá válik az agrárolló értéke. Amíg 2016-ban és 2018-ban a ráfordítások árai nagyobb mértékben nőttek, mint a felvásárlási árak, addig 2017-ben és 2019-ben az ellenkezője volt tapasztalható. A vállalkozások számára az utóbbi eset a kedvező (3. ábra). 


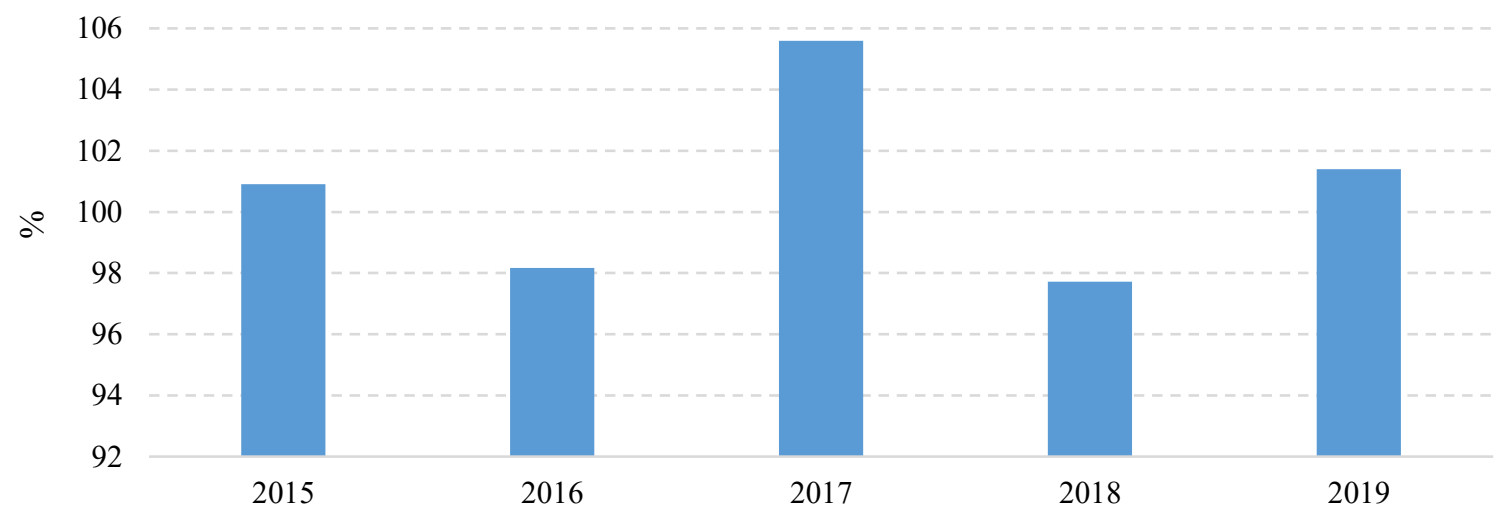

3. ábra: Az agrárolló alakulása (elóző év=100\%)

Forrás: KSH, $2020 b$

A KSH 2019-es adatai szerint a hazánkban kisebb arányban müködő társas vállalkozások a rendelkezésre álló 4,3 millió hektár szántóterület mintegy 38\%-át használják. A 2016-ban történt Gazdaságszerkezeti Összeírás (GSZÖ) szerint a gazdasági szervezetek száma 2010 óta folyamatosan növekedett, míg az egyéni gazdaságok száma a 2000-es évektől kezdődően jelentösen csökkent (543 ezerrel kevesebb) (KSH, 2020).

Hazánk a szántóföldi növénytermesztéshez kiváló adottsággal rendelkezik. Hajdú-Bihar megyében közel 325 ezer hektár szántóföld található (országos viszonylatban negyedik a rangsorban) (KSH, 2020b). Az egyes megyékben a szántóföldek minősége és azok piaci árai között jelentős eltérések tapasztalhatók. Annak ellenére, hogy Tolna és Békés megye rendelkezik a legkedvezőbb hektáronkénti átlagos aranykorona értékkel, mégsem csak ezekben a megyékben vannak a legmagasabb egy hektárra jutó szántóföldi árak. Az elemzések szerint Hajdú-Bihar megyében is elérhetővé válik a Tolna és Békés megyében tapasztalható szántóföldi árak, annak ellenére, hogy az aranykorona értéke átlagosan alacsonyabbnak tekinthető Hajdú-Bihar megyében. Itt a szántók átlagára 1,8 millió Ft/ha volt 2017-ben (Vinogradov - Takácsné György, 2019). Egy évvel később Hajdú-Bihar megyében már közel 2,1 millió Ft-ba került egy hektár szántóterület, amely országos viszonylatban a legnagyobb növekedést $(\sim 20 \%)$ eredményezte $(\mathrm{KSH}, 2020 \mathrm{a})$. Mindemellett olyan egyéb tényezők is befolyásolják a piaci árakat, mint például a „terület mérete, fekvése, megközelíthetősége, öntözhetősége”. „Közismert, hogy például löszháton, Debrecen, Hajdúszoboszló, Hajdúböszörmény és Ebes környékén találhatók a magas minőségü termőhelyek. E termőhelyek magas minőségét a talajok jó termőképességén túl a kedvező időjárási viszonyok is meghatározzák, ezen ökológiai tényezők együttese jobb minőségü és nagyobb mennyiségü termést eredményez.” (Vinogradov - Takácsné György, 2019).

A megyei és az országos termelési potenciál összehasonlításának alapját a termésátlagok adják. A 4. ábra jól szemlélteti, hogy a kukorica Hajdú-Bihar megyei termésátlagai meghaladják az országos átlagokét a vizsgált időszak alatt. Amennyiben a 2015-2019-es időszakot összevontan vizsgáljuk, akkor Hajdú-Bihar megyében 56\%-kal magasabb, (8,3 t/ha) volt a kukorica átlagos fajlagos terméshozama, mint Magyarországon (5,3 t/ha). Ez összhangban van Vinogradov Takácsné György (2019) megállapításaival, miszerint ebben a megyében kiváló talajadottságok vannak a magasabb terméshozam eléréséhez. Ezenkívül hozzá kell tenni, hogy kukoricát Hajdú-Bihar megyében termesztettek a legnagyobb területen, valamint itt is takarították be országos viszonylatban a legnagyobb mennyiséget 2017-ben és 2018-ban (KSH, 2018; 2019). Mindemellett az időjárási viszonyok is nagymértékben hozzájárulnak a kedvező termésátlagokhoz. A búza esetében nem tapasztalható ilyen mértékü különbség, a Hajdú-Bihar 
megyei társas vállalkozások mindössze 4\%-kal tudtak átlagosan magasabb fajlagos hozamot (5,5 t/ha) elérni az országos átlaghoz (5,3 t/ha) képest (4. ábra).

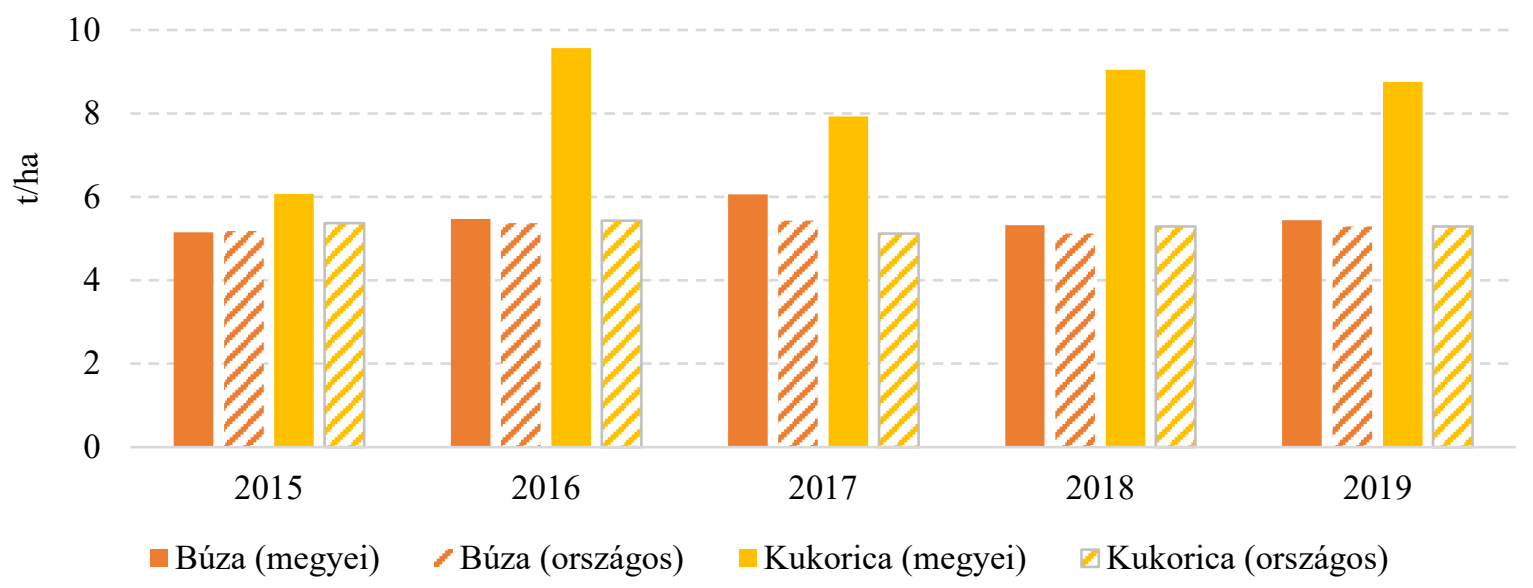

\section{4. ábra: A búza és a kukorica termésátlaga Hajdú-Bihar megyei és országos} viszonylatban

Forrás: KSH, $2020 b$

Megvizsgálva a 2015 és 2019 közötti időszakot a vizsgált Hajdú-Bihar megyei társas vállalkozások átlagosan 13\%-kal tudtak magasabb termésátlagot elérni napraforgóból (5. ábra). Ezzel szemben a repce megyei és országos termésátlaga hasonlóan alakult a vizsgált időszak alatt.

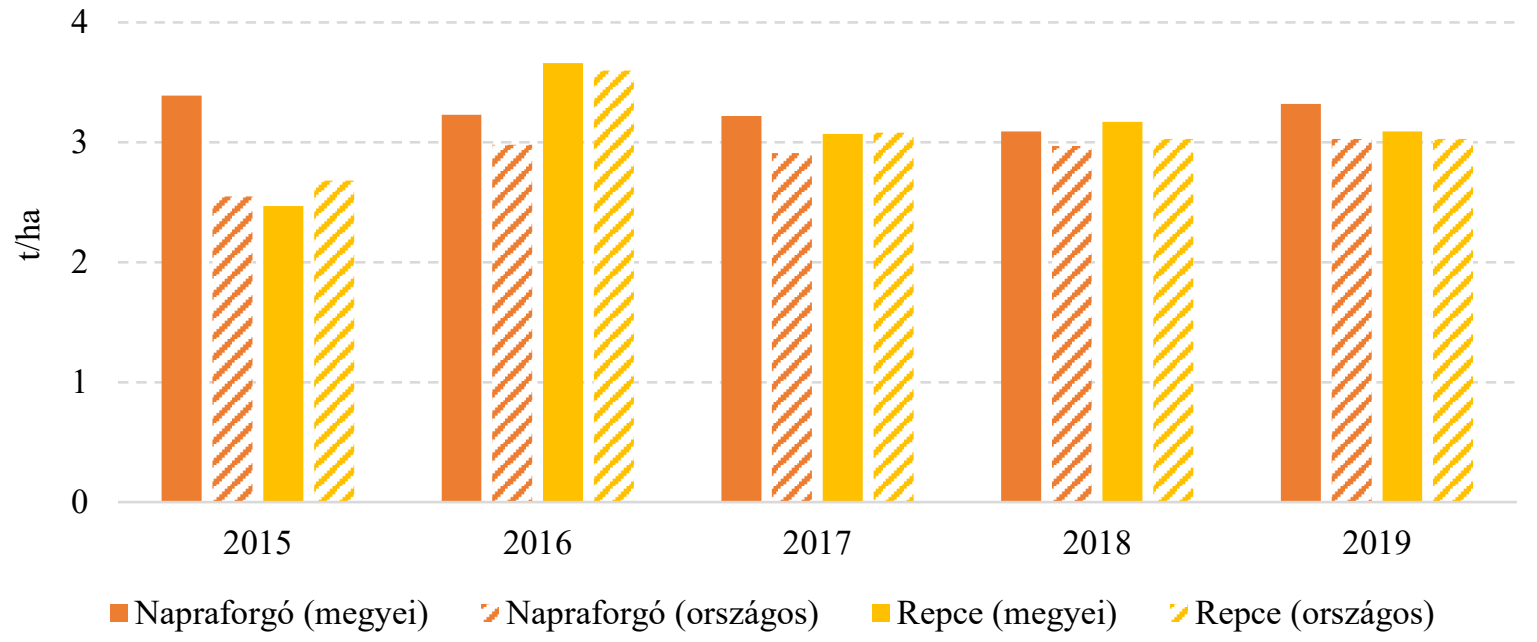

\section{5. ábra: A napraforgó és a repce termésátlaga Hajdú-Bihar megyei és országos} viszonylatban

Forrás: KSH, $2020 b$

A vizsgált társas vállalkozások üzemméretének alakulása

Ahhoz, hogy a vállalkozások jövedelmezöségét megfelelően értékeljük, vizsgáltuk az üzemméret alakulását is. Mivel a szántóterület nagysága nem állt rendelkezésünkre, ezért az üzemméretet a mérlegföösszeg és az értékesítés nettó árbevétele alapján értékeltük. 
A 2004. évi XXXIV. törvény szerint a gazdasági szervezetek méretei a következők lehetnek: mikro-, kis-, és középvállalkozás. Ezen üzemkategóriák besorolását a törvény euróban határozza meg. A 2015-2019-es időszakra vonatkozó MNB átlag euroárfolyam $(314,94$ HUF/EUR) alapján határoztuk meg az egyes kategóriák közötti intervallumokat. Mikrovállalkozásnak tekintjük azokat, amelyek 630 millió Ft-nál alacsonyabb mérlegföösszeggel és értékesítés nettó árbevétellel jellemezhetők. Kisvállalkozás tekintetében 3,15 milliárd Ft a felső értékhatár mind a mérlegföösszeg, mind az értékesítés nettó árbevétele esetében. A középvállalkozások maximum 13,5 milliárd $\mathrm{Ft}$ vagyonnal vagy 15,7 milliárd $\mathrm{Ft}$ árbevétellel rendelkeznek. E fölötti értékek esetében már nagyvállalatról beszélhetünk, azonban a vizsgált gazdaságok között nem található ilyen. Így az osztályközös megoszlás szemléltetésénél ezt a kategóriát nem jelöltük külön.

Országos viszonylatban a legalacsonyabb vagyonnal (630 millió Ft alatti) rendelkezők aránya közel 52\%. Ez az arány hasonló Hajdú-Bihar megyében és ezen belül Hajdúböszörményben is. A kisvállalkozások aránya hazai szinten mintegy 43\%, megyei viszonylatban 36\%. Hajdúböszörményben egy vállalkozás tartozik ebbe a kategóriába. A legmagasabb vagyonnal rendelkezők a vizsgált üzemek közel 6\%-át jelentik országos viszonylatban, ez az arány HajdúBihar megyében magasabb (mintegy 10\%). Ezen belül egy hajdúböszörményi cég is a középkategóriába sorolható be. Ezenkívül megállapítható, hogy a hajdúböszörményi üzemek átlagosan közel kétszer akkora vagyonnal rendelkeznek a megyei és országos átlagértékekhez viszonyítva (1. táblázat).

\section{1. táblázat: A vállalkozások méretének alakulása mérlegföösszeg alapján (2015-2019 időszak átlagában)}

\begin{tabular}{|c|c|c|c|c|c|c|c|}
\hline \multirow{2}{*}{$\begin{array}{c}\text { KKV } \\
\text { kategó- } \\
\text { ria }\end{array}$} & \multirow{2}{*}{$\begin{array}{l}\text { Mérlegfö- } \\
\text { összeg } \\
\text { (millió Ft) }\end{array}$} & \multicolumn{2}{|c|}{ Magyarország } & \multicolumn{2}{|c|}{ Hajdú-Bihar megye } & \multicolumn{2}{|c|}{ Hajdúböszörmény } \\
\hline & & $\begin{array}{l}\text { Vállalkozások } \\
\text { száma (db) }\end{array}$ & $\begin{array}{l}\text { Megoszlás } \\
\text { (\%) }\end{array}$ & $\begin{array}{l}\text { Vállalkozások } \\
\text { száma (db) }\end{array}$ & $\begin{array}{c}\text { Megoszlás } \\
\text { (\%) }\end{array}$ & $\begin{array}{l}\text { Vállalkozások } \\
\text { száma (db) }\end{array}$ & $\begin{array}{c}\text { Megoszlás } \\
\text { (\%) }\end{array}$ \\
\hline Mikro & $0-629,9$ & 442 & 51,82 & 37 & 53,62 & 2 & 50,00 \\
\hline \multirow{4}{*}{ Kis } & 630-999,9 & 161 & 18,87 & 15 & 21,74 & 1 & 25,00 \\
\hline & $\begin{array}{l}1000- \\
1499,9\end{array}$ & 103 & 12,08 & 5 & 7,25 & 0 & 0,00 \\
\hline & $\begin{array}{l}1500- \\
1999,9\end{array}$ & 57 & 6,68 & 2 & 2,90 & 0 & 0,00 \\
\hline & $\begin{array}{l}2000- \\
3149,9\end{array}$ & 42 & 4,92 & 3 & 4,35 & 0 & 0,00 \\
\hline Közép & $3150<=$ & 48 & 5,63 & 7 & 10,14 & 1 & 25,00 \\
\hline \multicolumn{2}{|c|}{ Összesen } & 853 & 100,00 & 69 & 100,00 & 4 & 100,00 \\
\hline \multicolumn{2}{|c|}{ Átlag (millió Ft) } & 997 & - & 1064 & - & 1955 & - \\
\hline \multicolumn{2}{|c|}{ Relatív szórás (\%) } & 122,26 & - & 122,59 & - & 141,85 & - \\
\hline
\end{tabular}

Forrás: EMIS adatok alapján saját számítás, 2020

Megvizsgálva az értékesítés nettó árbevételének alakulását a 2015-2019-es időszak átlagában, megállapítható, hogy hazai szinten és ezen belül a hajdúböszörményi vállalkozások esetében is a vizsgált üzemek 75\%-a mikrovállalkozásnak tekinthető, azaz 630 millió Ft alatti értékkel rendelkezik. Hajdú-Bihar megyében ez az arány magasabb (81\%). A hajdúböszörményi társas vállalkozások közül egy üzem a kisvállalkozások méretkategóriáján belül a legfelső osztályközbe sorolható be, ahol országos viszonylatban mindössze 21 cég, megyei viszonylatban 3 cég van (2. táblázat). Megemlítendő, hogy Hajdú-Bihar megyében nem található közép kategóriájú vállalkozás. 
2. táblázat: A vállalkozások méretének alakulása értékesítés nettó árbevétele alapján (2015-2019 időszak átlagában)

\begin{tabular}{|c|c|c|c|c|c|c|c|}
\hline \multirow{2}{*}{$\begin{array}{c}\text { KKV } \\
\text { kategó- } \\
\text { ria }\end{array}$} & \multirow{2}{*}{$\begin{array}{c}\text { Értékesítés } \\
\text { nettó } \\
\text { árbevétele } \\
\text { (millió Ft) }\end{array}$} & \multicolumn{2}{|c|}{ Magyarország } & \multicolumn{2}{|c|}{ Hajdú-Bihar megye } & \multicolumn{2}{|c|}{ Hajdúböszörmény } \\
\hline & & $\begin{array}{l}\text { Vállalkozáso } \\
\text { k száma (db) }\end{array}$ & $\begin{array}{l}\text { Megoszlás } \\
\text { (\%) }\end{array}$ & $\begin{array}{l}\text { Vállalkozáso } \\
\text { k száma (db) }\end{array}$ & $\begin{array}{c}\text { Megoszlás } \\
(\%)\end{array}$ & $\begin{array}{l}\text { Vállalkozáso } \\
\text { k száma (db) }\end{array}$ & $\begin{array}{c}\text { Megoszlás } \\
(\%)\end{array}$ \\
\hline Mikro & $0-629,9$ & 636 & 74,56 & 56 & 81,16 & 3 & 75,00 \\
\hline \multirow{4}{*}{ Kis } & $630-999,9$ & 103 & 12,08 & 5 & 7,25 & 0 & 0,00 \\
\hline & $1000-1499,9$ & 62 & 7,27 & 5 & 7,25 & 0 & 0,00 \\
\hline & 1500-1999,9 & 20 & 2,34 & 0 & 0,00 & 0 & 0,00 \\
\hline & 2000-3149,9 & 21 & 2,46 & 3 & 4,35 & 1 & 25,00 \\
\hline Közép & $3150<=$ & 11 & 1,29 & 0 & 0,00 & 0 & 0,00 \\
\hline \multicolumn{2}{|c|}{ Összesen } & 853 & 100,00 & 69 & 100,00 & 4 & 100,00 \\
\hline \multicolumn{2}{|c|}{ Átlag (millió Ft) } & 546 & - & 506 & - & 869 & - \\
\hline \multicolumn{2}{|c|}{ Relatív szórás (\%) } & 118,48 & - & 93,19 & - & 114,17 & - \\
\hline
\end{tabular}

Forrás: EMIS adatok alapján saját számítás, 2020

Az értékesítés nettó árbevételének alakulása látható a 6. ábrán 2015 és 2019 között. Kijelenthető, hogy a hajdúböszörményi gazdaságok átlagosan magasabb árbevételt tudtak elérni a megyei és az országos értékekhez képest. A vizsgált időszak átlagában 1,5-1,7-szeres árbevétellel rendelkeztek ezen gazdaságok.

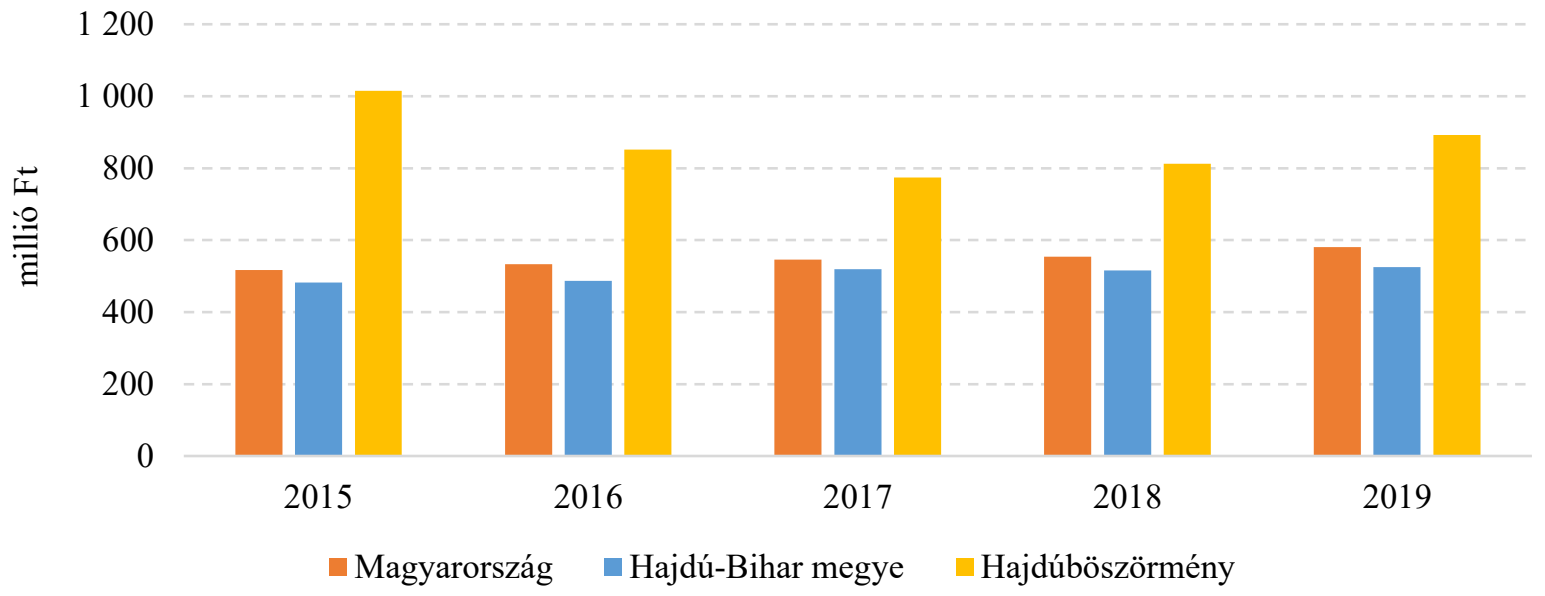

6. ábra: Értékesítés nettó árbevételének alakulása 2015-2019 között

Forrás: EMIS adatok alapján saját számítás, 2020

\section{A jövedelem és jövedelmezöség alakulása}

Amíg a vizsgált üzemek közel kétharmada 45 millió Ft alatti, addig közel 20\%-a 75 millió Ft feletti üzemi üzleti tevékenység eredménnyel rendelkezett 2015-2019-es időszak átlagában. Hajdú-Bihar megyében ennél valamelyest magasabb (70\%) azon vállalkozások aránya, amelyek 45 millió Ft alatti jövedelmet realizáltak az adott időszak alatt. Ezenkívül közel 15\%os megoszlást mutatnak azok a gazdaságok, amelyek a legmagasabb jövedelem elérését tudták realizálni (75 millió Ft feletti). A megyén belül, Hajdúböszörményben a vizsgált üzemek fele 30 és 60 millió Ft közötti üzemi üzleti tevékenység eredménnyel rendelkeztek. Ezenkívül megtalálható közöttük 15 millió Ft alatti és 75 millió Ft feletti gazdaság is. Utóbbi országos viszonylatban a felső 20\%-ba tartozik (3. táblázat). 
3. táblázat: A vállalkozások jövedelmének alakulása az üzemi üzleti tevékenység eredménye alapján (2015-2019 időszak átlagában)

\begin{tabular}{|c|c|c|c|c|c|c|}
\hline \multirow{2}{*}{$\begin{array}{c}\text { Üzemi üzleti } \\
\text { tevékenység eredménye } \\
\text { (millió } \mathrm{Ft})\end{array}$} & \multicolumn{2}{|c|}{ Magyarország } & \multicolumn{2}{|c|}{ Hajdú-Bihar megye } & \multicolumn{2}{|c|}{ Hajdúböszörmény } \\
\hline & $\begin{array}{l}\text { Vállalkozások } \\
\text { száma (db) }\end{array}$ & $\begin{array}{c}\text { Megoszlá } \\
\text { s (\%) }\end{array}$ & $\begin{array}{l}\text { Vállalkozások } \\
\text { száma (db) }\end{array}$ & $\begin{array}{c}\text { Megoszlás } \\
(\%)\end{array}$ & $\begin{array}{l}\text { Vállalkozáso } \\
\text { k száma (db) }\end{array}$ & $\begin{array}{c}\text { Megoszlás } \\
(\%)\end{array}$ \\
\hline $0-14,9$ & 280 & 32,83 & 21 & 30,43 & 1 & 25,00 \\
\hline $15-29,9$ & 170 & 19,93 & 18 & 26,09 & 0 & 0,00 \\
\hline $30-44,9$ & 104 & 12,19 & 9 & 13,04 & 1 & 25,00 \\
\hline $45-59,9$ & 74 & 8,68 & 7 & 10,14 & 1 & 25,00 \\
\hline $60-74,9$ & 52 & 6,10 & 4 & 5,80 & 0 & 0,00 \\
\hline $75<=$ & 173 & 20,28 & 10 & 14,49 & 1 & 25,00 \\
\hline Összesen & 853 & 100,00 & 69 & 100,00 & 4 & 100,00 \\
\hline Átlag (millió Ft) & 47 & - & 42 & - & 144 & - \\
\hline Relatív szórás (\%) & 155,92 & - & 196,65 & - & 156,30 & - \\
\hline
\end{tabular}

Forrás: EMIS adatok alapján saját számitás, 2020

A 7. ábra jól szemlélteti, hogy az egyes években a hajdúböszörményi gazdaságok átlagosan 33,5-szer magasabb jövedelmet tudtak elérni, amely egyrészt az üzemméretettel, másrészt a hatékonyabb költséggazdálkodással magyarázható. Ez utóbbi alátámasztásához a jövedelmezőségi mutatók összehasonlítása célszerü.

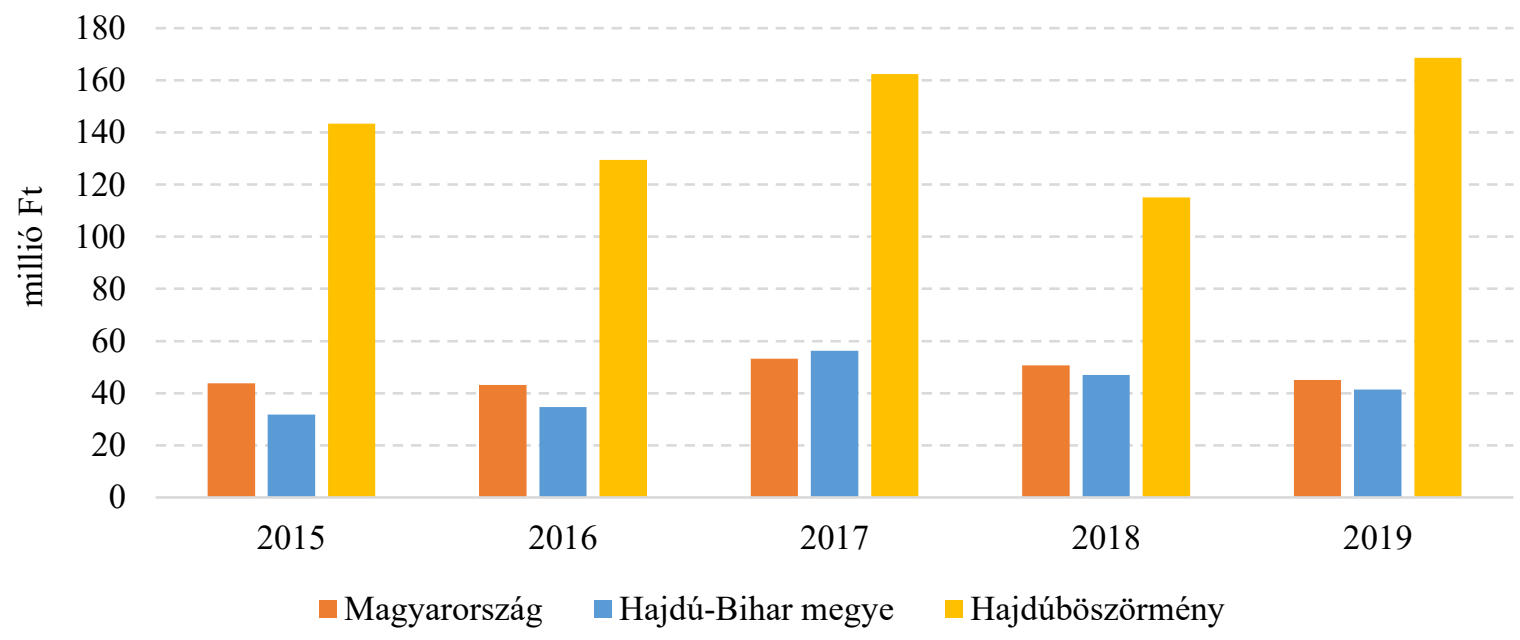

7. ábra: Üzemi üzleti tevékenység eredményének alakulása 2015-2019 között

Forrás: EMIS adatok alapján saját számitás, 2020

A müködési ROS alapján való osztályközös megoszlást szemlélteti a 4. táblázat. Hazai viszonylatban a vizsgált társas vállalkozások mintegy kétharmada $0-15 \%$ közötti müködési ROS értéket ért el 2015-2019-es időszak átlagában. Megyei szinten hasonló megállapítás fogalmazható meg. Amíg országos és megyei szinten az tapasztalható, hogy a legjövedelmezőbb gazdaságok átlagosan kisüzemek, addig Hajdúböszörményben középvállalkozásoknak tekinthetők. Ugyanakkor a korreláció-elemzés során a müködési ROS és a mérlegföösszeg $(\mathrm{r}=0,040 ; \mathrm{p}=0,243)$, valamint a ROS és az árbevétel $(\mathrm{r}=0,045 ; \mathrm{p}=0,190)$ között nem mutatható ki statisztikailag igazolható kapcsolat. A vizsgált hajdúböszörményi gazdaságok fele 0-10\% közötti, illetve másik fele átlagosan 15\%-nál magasabb müködési ROSt tudtak elérni. 
4. táblázat: A múködési ROS alakulása a vizsgált vállalkozások esetében (2015-2019 időszak átlagában)

\begin{tabular}{|c|c|c|c|c|c|c|}
\hline \multirow{2}{*}{$\begin{array}{c}\text { Múködési ROS } \\
\text { (\%) }\end{array}$} & \multicolumn{2}{|c|}{ Magyarország } & \multicolumn{2}{|c|}{ Hajdú-Bihar megye } & \multicolumn{2}{|c|}{ Hajdúböszörmény } \\
\hline & $\begin{array}{l}\text { Vállalkozáso } \\
\text { k száma (db) }\end{array}$ & $\begin{array}{c}\text { Megoszlás } \\
(\%)\end{array}$ & $\begin{array}{l}\text { Vállalkozáso } \\
\text { k száma (db) }\end{array}$ & $\begin{array}{c}\text { Megoszlás } \\
(\%)\end{array}$ & $\begin{array}{l}\text { Vállalkozáso } \\
\text { k száma (db) }\end{array}$ & $\begin{array}{c}\text { Megoszlás } \\
(\%)\end{array}$ \\
\hline$<0$ & 106 & 12,43 & 8 & 11,59 & 0 & 0,00 \\
\hline $0-4,9$ & 187 & 21,92 & 17 & 24,64 & 1 & 25,00 \\
\hline $5-9,9$ & 218 & 25,56 & 20 & 28,99 & 1 & 25,00 \\
\hline $10-14,9$ & 132 & 15,47 & 8 & 11,59 & 0 & 0,00 \\
\hline $15-19,9$ & 90 & 10,55 & 7 & 10,14 & 1 & 25,00 \\
\hline $20<=$ & 120 & 14,07 & 9 & 13,04 & 1 & 25,00 \\
\hline Összesen & 853 & 100,00 & 69 & 100,00 & 4 & 100,00 \\
\hline Átlag (\%) & 5,30 & - & 8,90 & - & 12,53 & - \\
\hline $\begin{array}{l}\text { Relatív szórás } \\
(\%)\end{array}$ & 1147,97 & - & 167,79 & - & 71,40 & - \\
\hline
\end{tabular}

Forrás: EMIS adatok alapján saját számítás, 2020

A müködési ROS éves értékeinek alakulását mutatja be a 8 . ábra. Jól látható, hogy a hajdúböszörményi vállalkozások mind az országos, mind a megyei átlaghoz viszonyítva átlagosan költséghatékonyabban tudnak termelni, azaz viszonylag alacsonyabb költséggel tudtak magasabb jövedelmet realizálni. A 2019-ben országos viszonylatban elért negatív müködési ROS értékének hátterében döntően a rendkívül alacsony jövedelemtermelöképességgel rendelkező vállalkozások nagyobb aránya befolyásolta az egyszerű számtani átlag értékét.

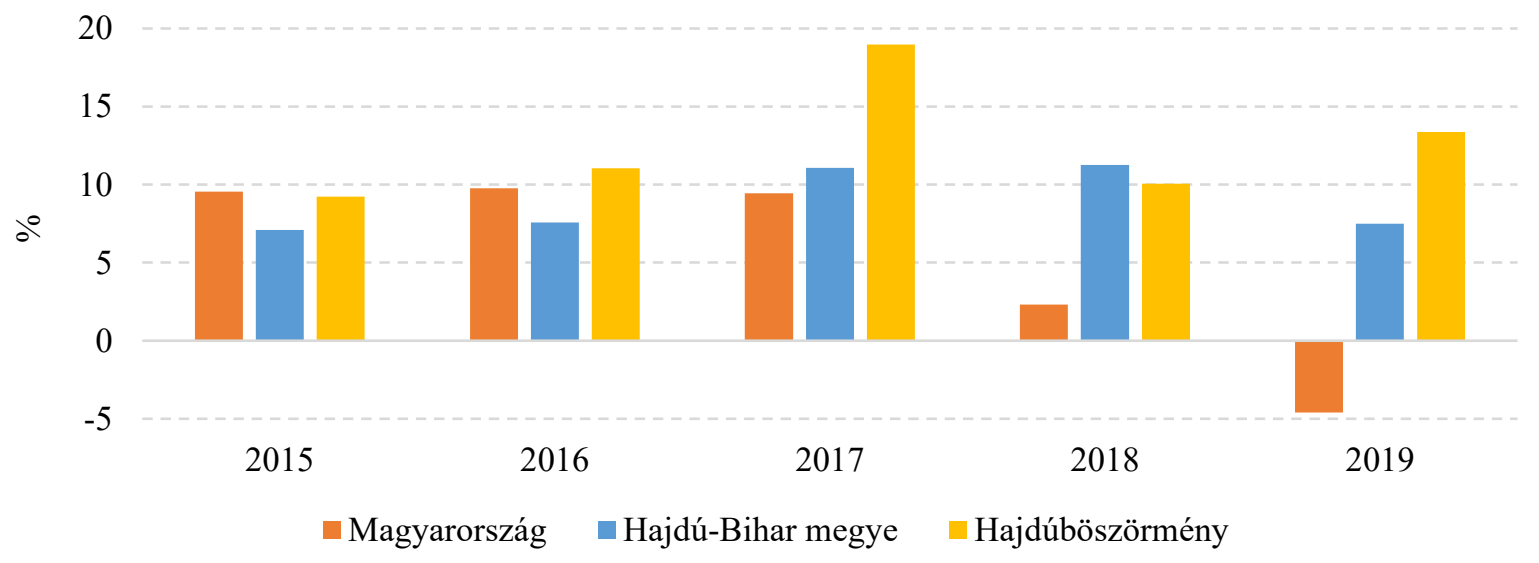

8. ábra: A müködési ROS alakulása 2015-2019 között

Forrás: EMIS adatok alapján saját számítás, 2020

A vizsgált vállalkozások ROE szerinti megoszlását mutatja be az 5. táblázat. Hazai szinten az üzemek 70\%-a 0-15\%-os ROE értékkel rendelkezik. Megyei szinten ez az érték 76\%. Ezzel szemben a hajdúböszörményi gazdaságok háromnegyede 5-15\% közötti ROE értéket ért el. Ezenkívül a legjövedelmezöbb üzemek országos, megyei és hajdúböszörményi viszonylatban is átlagosan mikrovállalkozásoknak tekinthetők. Ugyanakkor országos viszonylatban a ROE mutató és a mérlegföösszeg között $(\mathrm{r}=-0,014 ; \mathrm{p}=0,681)$, valamint a $\mathrm{ROE}$ és az árbevétel között $(\mathrm{r}=0,026 ; \mathrm{p}=0,452)$ nem mutatható ki statisztikailag összefüggés. 
5. táblázat: A saját tőke müködési hozamának alakulása a vizsgált vállalkozások esetében (2015-2019 időszak átlagában)

\begin{tabular}{|c|c|c|c|c|c|c|}
\hline \multirow{2}{*}{$\begin{array}{c}\text { Saját tőke } \\
\text { müködési hozama } \\
(\%)\end{array}$} & \multicolumn{2}{|c|}{ Magyarország } & \multicolumn{2}{|c|}{ Hajdú-Bihar megye } & \multicolumn{2}{|c|}{ Hajdúböszörmény } \\
\hline & $\begin{array}{l}\text { Vállalkozáso } \\
\text { k száma (db) } \\
\end{array}$ & $\begin{array}{c}\text { Megoszlás } \\
(\%)\end{array}$ & $\begin{array}{l}\text { Vállalkozáso } \\
\text { k száma (db) }\end{array}$ & $\begin{array}{c}\text { Megoszlás } \\
(\%)\end{array}$ & $\begin{array}{l}\text { Vállalkozáso } \\
\text { k száma (db) } \\
\end{array}$ & $\begin{array}{c}\text { Megoszlás } \\
(\%)\end{array}$ \\
\hline$<0$ & 105 & 12,44 & 8 & 11,76 & 0 & 0,00 \\
\hline $0-4,9$ & 229 & 27,13 & 24 & 35,29 & 1 & 25,00 \\
\hline $5-9,9$ & 235 & 27,84 & 17 & 25,00 & 2 & 50,00 \\
\hline $10-14,9$ & 139 & 16,47 & 11 & 16,18 & 1 & 25,00 \\
\hline $15-19,9$ & 62 & 7,35 & 4 & 5,88 & 0 & 0,00 \\
\hline $20<$ & 74 & 8,77 & 4 & 5,88 & 0 & 0,00 \\
\hline Összesen & 844 & 100,00 & 68 & 100,00 & 4 & 100,00 \\
\hline Átlag (\%) & 8,15 & - & 6,31 & - & 8,29 & - \\
\hline $\begin{array}{l}\text { Relatív szórás } \\
(\%)\end{array}$ & 476,82 & - & 249,44 & - & 37,66 & - \\
\hline
\end{tabular}

Forrás: EMIS adatok alapján saját számítás, 2020

Az egyes években elérhető ROE értékét mutatja be a 9. ábra. Hazai szinten a vizsgált vállalkozások 2016-ban rendelkeztek átlagosan legmagasabb egységnyi saját tőkével előállított jövedelemmel. Ennek hátterében a 9\%-os támogatási összegek növekedése állhat, mely kedvezően befolyásolta a gazdaságok jövedelmezőségét, ellenben az ezt megelőző évben, amikor átlagosan 12\%-kal csökkentek (Keszthelyi, 2017; Keszthelyi - Kis Csatári, 2018). 2017-től kezdődően azonban átlagosan alacsonyabb mértékben növekedtek a támogatások (57\%-kal) (Keszthelyi - Kis Csatári, 2019; 2020).

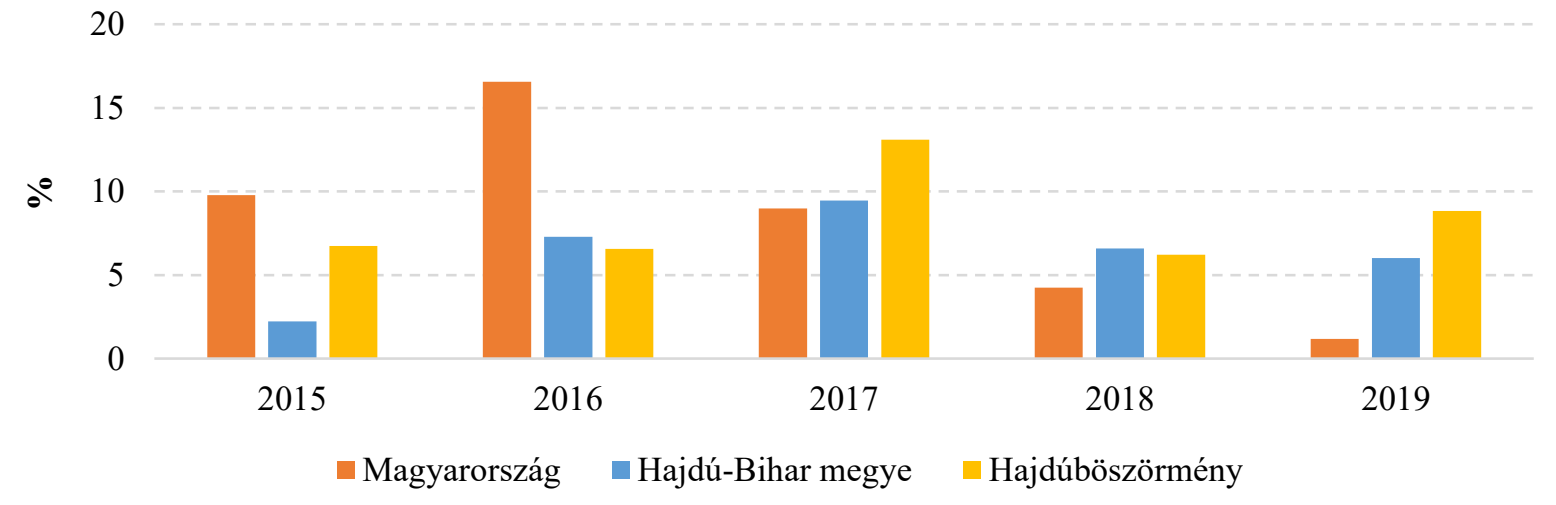

9. ábra: A saját tőke működési hozamának alakulása 2015-2019 között

Forrás: EMIS adatok alapján saját számitás, 2020

A ROI értékeit megvizsgálva az állapítható meg, hogy a Hajdú-Bihar megyei, illetve ezen belül a hajdúböszörményi társas vállalkozások alacsonyabb befektetett eszközarányos jövedelmezőségi mutatóval rendelkeznek annak ellenére, hogy a hajdúböszörményi gazdálkodók átlagosan magasabb befektetett eszközaránnyal (55\%) és befektetett eszközértékkel rendelkeznek ( 1 milliárd $\mathrm{Ft}$ ), mint az országos átlagadatok (50\% és 516 millió $\mathrm{Ft}$ ). A magasabb befektetett eszközérték és annak aránya vélhetően az újabb és korszerübb eszközökre vezethető vissza. Országos viszonylatban a vizsgált vállalkozások több mint fele 0 15\%-os ROI értékkel rendelkezik, 22\%-a pedig a legjövedelmezőbb kategóriába tartozik és kisvállalkozásnak tekinthető. Ezzel szemben a hajdúböszörményi gazdálkodók körében átlagosan közép méretüek a legjövedelmezöbbek (6. táblázat). Országos viszonylatban a ROI 
mutató és a mérlegföösszeg között $(\mathrm{r}=-0,023 ; \mathrm{p}=0,494)$, valamint a ROI és az árbevétel között $(\mathrm{r}=-0,001 ; \mathrm{p}=0,974)$ nem mutatható ki szignifikáns összefüggés.

\section{6. táblázat: A ROI alakulása a vizsgált vállalkozások esetében (2015-2019 időszak átlagában)}

\begin{tabular}{|c|c|c|c|c|c|c|}
\hline \multirow{2}{*}{$\begin{array}{c}\text { Befektetett } \\
\text { eszközarányos } \\
\text { jövedelmezőség } \\
(\%) \\
\end{array}$} & \multicolumn{2}{|c|}{ Magyarország } & \multicolumn{2}{|c|}{ Hajdú-Bihar megye } & \multicolumn{2}{|c|}{ Hajdúböszörmény } \\
\hline & $\begin{array}{l}\text { Vállalkozáso } \\
\text { k száma (db) }\end{array}$ & $\begin{array}{c}\text { Megoszlás } \\
\text { (\%) }\end{array}$ & $\begin{array}{l}\text { Vállalkozáso } \\
\text { k száma (db) }\end{array}$ & $\begin{array}{c}\text { Megoszlás } \\
(\%)\end{array}$ & $\begin{array}{l}\text { Vállalkozáso } \\
\text { k száma (db) }\end{array}$ & $\begin{array}{c}\text { Megoszlás } \\
\text { (\%) }\end{array}$ \\
\hline$<0$ & 104 & 12,19 & 8 & 11,59 & 0 & 0,0 \\
\hline $0-4,9$ & 149 & 17,47 & 7 & 10,14 & 0 & 0,0 \\
\hline $5-9,9$ & 177 & 20,75 & 24 & 34,78 & 2 & 50,0 \\
\hline $10-14,9$ & 141 & 16,53 & 13 & 18,84 & 0 & 0,0 \\
\hline $15-19,9$ & 97 & 11,37 & 6 & 8,70 & 2 & 50,0 \\
\hline $20<=$ & 185 & 21,69 & 11 & 15,94 & 0 & 0,0 \\
\hline Összesen & 853 & 100,00 & 69 & 100,00 & 4 & 100,0 \\
\hline Átlag (\%) & 16,41 & - & 10,89 & - & 12,87 & - \\
\hline $\begin{array}{l}\text { Relatív szórás } \\
(\%)\end{array}$ & 510,83 & - & 211,56 & - & 46,22 & - \\
\hline
\end{tabular}

Forrás: EMIS adatok alapján saját számítás, 2020

A ROI egyes évekre vonatkozó értékeit szemlélteti a 10. ábra. Ezen időszak alatt változóan alakultak a hajdúböszörményi üzemek befektetett eszközarányos jövedelmezőségi mutatója, mindössze 2017-ben és 2019-ben haladta meg a megyei és az országos átlagértékeket. Országos viszonylatban azonban kiemelkedő a 2016-os év, amikor a hazai vállalkozások átlagosan 30\% körüli ROI értéket tudtak elérni. Ennek hátterében a támogatási szabályozások módosítása állhat. Az 1200 hektár felett rendelkező üzemek nem kaphatták meg a területalapú támogatás összegét. Ebből kifolyólag a kis- és középvállalkozások tekintetében jelentősen növekedett a beruházási hajlandóság (61\%-kal és $15 \%$-kal). Ezzel szemben a nagy üzemméretü gazdaságok esetében 14\%-kal csökkent (Keszthelyi - Kis Csatári, 2018).

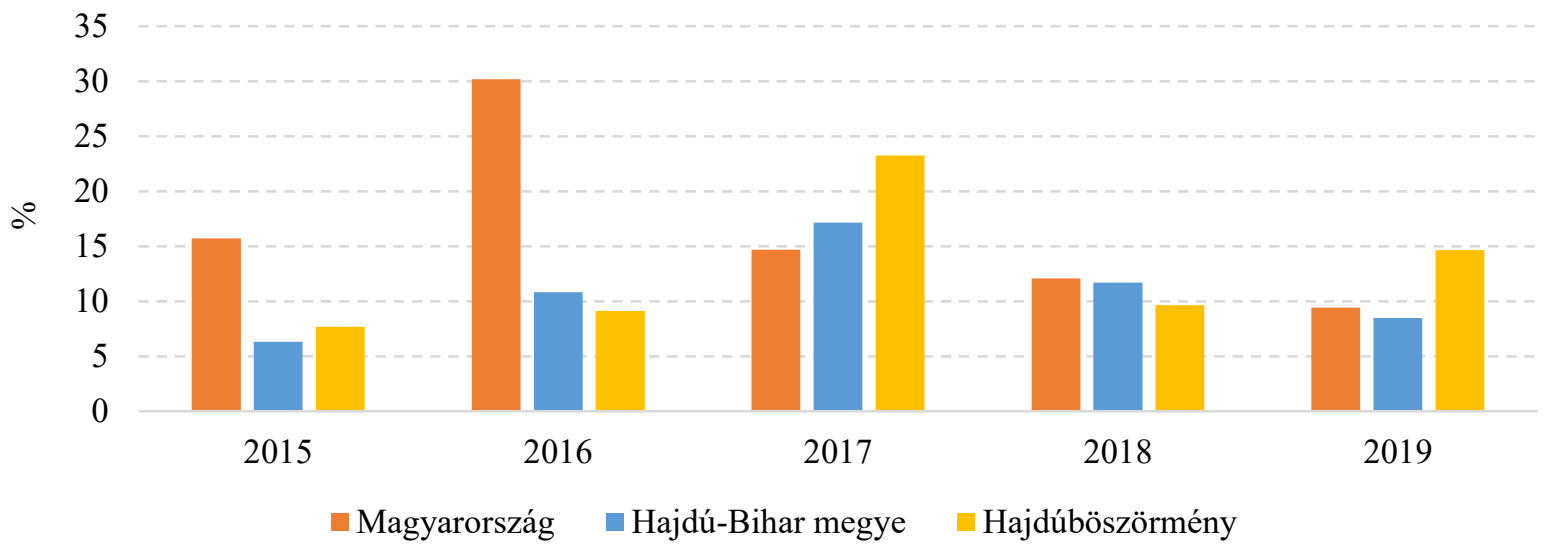

10. ábra: ROI alakulása 2015-2019 között

Forrás: EMIS adatok alapján saját számitás, 2020

A naturális és ökonómiai hatékonyság szorosan összefügg, ugyanis az egységnyi területen elérhető terméshozam hatással van az adott vállalkozás (hatékonyságára) jövedelmezőségére, amit Nemessályi (2005) megállapítása is alátámaszt. Ezért megvizsgáltuk a főbb szántóföldi növények termésátlagai és a kalkulált jövedelmezöségi mutatók közötti kapcsolatot. 
A Hajdú-Bihar megyei társas vállalkozások 2015-2019-es időszakra vonatkozó megyei átlagos jövedelmezőségi mutatói valamint a megyei átlagos termésátlagok közötti korrelációelemzés eredményét mutatja be a 13. táblázat. Ez alapján a ROE és a búza termésátlaga között statisztikailag igazolható, erős pozitív irányú kapcsolat áll fenn. A müködési ROS és a napraforgó termésátlaga között erős negatív irányú szignifikáns kapcsolatot mutattunk ki. A ROI és a búza termésátlaga közötti kapcsolat szintén igazolható statisztikailag, amely erös pozitív összefüggést mutat.

7. táblázat: Az egyes jövedelmezőségi mutatók és termésátlagok közötti kapcsolatok vizsgálata (Hajdú-Bihar megyei átlagadatok alapján) $(n=69)$

\begin{tabular}{|l|r|r|r|r|}
\hline \multirow{2}{*}{ Jövedelmezőségi mutatók (\%) } & \multicolumn{4}{|c|}{ Termésátlag $(\mathrm{t} / \mathrm{ha})$} \\
\cline { 2 - 5 } & \multicolumn{1}{|c|}{ Búza } & \multicolumn{1}{|c|}{ Kukorica } & \multicolumn{1}{c|}{ Napraforgó } & \multicolumn{1}{c|}{ Repce } \\
\hline \multirow{2}{*}{ Müködési ROS } & $\begin{array}{r}0,542 \\
(\mathrm{p}=0,345)\end{array}$ & $\begin{array}{r}0,233 \\
(\mathrm{p}=0,706)\end{array}$ & $\begin{array}{r}-0,814^{*} \\
(\mathrm{p}=0,094)\end{array}$ & $\begin{array}{r}0,144 \\
(\mathrm{p}=0,817)\end{array}$ \\
\hline \multirow{2}{*}{ ROE } & $\begin{array}{r}0,824^{*} \\
(\mathrm{p}=0,086)\end{array}$ & $\begin{array}{r}0,662 \\
(\mathrm{p}=0,224)\end{array}$ & $-0,581$ & $(0,304)$ \\
\hline \multirow{2}{*}{ ROI } & $\begin{array}{r}0,911^{* *} \\
(\mathrm{p}=0,032)\end{array}$ & $\begin{array}{r}0,327 \\
(\mathrm{p}=0,573\end{array}$ & $-0,125)$ \\
& & & $-0,608$ & 0,396 \\
$(\mathrm{p}=0,276)$ & $(\mathrm{p}=0,510)$ \\
\hline
\end{tabular}

${ }^{*} p<0,1 ; * * p<0,05$

Forrás: KSH és EMIS adatok alapján saját számítás, 2020

\section{Következtetések}

Összességében megállapítható, hogy mind a Hajdú-Bihar megyei, mind a hajdúböszörményi szántóföldi növénytermesztéssel foglalkozó társas vállalkozások - hasonlóan a magyarországi üzemekhez - jövedelmezően termelnek, azonban a vizsgált gazdaságok üzemméretei között eltérések voltak tapasztalhatók (Hajdúböszörményben 2 mikro-, 1 kis- és 1 középvállalkozás). Utóbbi jelentősen befolyásolta az átlagértékek kedvezőbb irányba történő elmozdulását. A hajdúböszörményi gazdaságok átlagos összes vagyona, átlagos értékesítési nettó árbevétele és átlagos üzemi tevékenységének eredménye is meghaladja nemcsak a megyei, de az országos átlagadatokat is. A jövedelmezőségi mutatók közül a müködési ROS is ezt mutatja, azaz a hajdúböszörményi cégek átlagosan alacsonyabb költséggel magasabb jövedelmet tudnak elérni. Amíg az országos és megyei viszonylatban a legjövedelmezőbb vállalkozások kisméretủek, addig a hajdúböszörményi gazdaságok átlagosan közepes méretüeknek tekinthetőek. A ROE alapján a hajdúböszörményi üzemek átlagosan a hazai átlagértékhez hasonlót értek el. Megyei szinten ez valamelyest alacsonyabbnak bizonyult. Az előző mutatókkal szemben a hajdúböszörményi cégek alacsonyabb ROI értéket mutatnak a vizsgált időszakban, amely mögött a magasabb befektetett eszközarány emelhetö ki. Ez pedig arra utalhat, hogy újabb és korszerübb eszközöket alkalmaznak a hajdúböszörményi üzemek, amely a költséghatékonyságon keresztül a müködési ROS értékében is megmutatkozik.

A Hajdú-Bihar megyei termésátlagok és az egyes jövedelmezőségi mutatók között csak némely esetben lehetett szignifikáns összefüggést kimutatni. A búza termésátlaga mind a ROE, mind a ROI mutatóval statisztikailag is igazolható erős pozitív kapcsolatban áll. Ezzel szemben a müködési ROS és a napraforgó termésátlaga között erős negatív szignifikáns kapcsolat mutatható ki. Ezek az eredmények azt is mutatják, hogy a termésátlagok mellett más tényezők (pl. termelői és ráfordítások árszínvonal-változásai, talajminőség, időjárási körülmények) is befolyásolják a jövedelemtermelőképességet, amelyek kimutatása további statisztikai elemzéseket igényel. 
Mindemellett úgy véljük, hogy a tanulmány elkészítéséhez felhasznált adatbázis és módszertan lehetővé teszi a vizsgálat kiterjesztését, akár az egyes megyei adatok összevetését, akár hazai, illetve nemzetközi összehasonlításokat is.

\section{Köszönetnyilvánítás}

„Az Innovációs és Technológiai Minisztérium ÚNKP-20-3 kódszámú Új Nemzeti Kiválóság Programjának a Nemzeti Kutatási, Fejlesztési és Innovációs Alapból finanszírozott szakmai támogatásával készült."

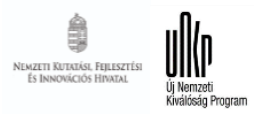

\section{Irodalomjegyzék}

1. 2004. évi XXXIV. törvény: A kis- és középvállalkozásokról, fejlődésük támogatásáról. Letöltés: https://net.jogtar.hu/jogszabaly?docid=a0400034.tv

2. Apáti F. - Tóth-Kurmai V. - Kicska T. - Kovács E. - Dorogi D. (2018a): A mütrágya nemzetközi és hazai piaci tendenciái (2. rész). Zöldség-Gyümölcs Piac és Technológia. Vol. 22. No. 2. pp. 32-35.

3. Apáti F. - Nábrádi A. - Szőllősi L. - Szűcs I. (2018b): Üzemtan. Debreceni Egyetem. Debrecen. pp. 31-32. ISBN 978-963-490-139-6.

4. Bareith T. - Koroseczné PavlinR. - Kövér Gy. (2014): Felszámolások vizsgálata a Nyugat-dunántúli régióban. E-CONOM. Vol. 3. No. 2. pp. 102-124. DOI: 10.17836/EC.2014.2.102

5. EMIS (2020): adatbázis. Letöltés: https://www.emis.com/php/dashboard/index

6. Fenyves V. - Nyul B. - Dajnoki K. - Bács Z. - Tömöri G. (2019): Profitability of Pharmaceutical Companies in the Visegrád Countries. Montenegrin Journal of Economics. Vol. 15. No. 4. pp. 99-111. DOI: 10.14254/1800-5845/2019.15-4.8

7. Fenyves V. - Pető K. - Szenderák J. - Harangi-Rákos M. (2020): Agricultural economics - Zemedelska Economica. Vol. 66. No. 4. pp. 160-167. DOI: 10.17221/285/2019-AGRICECON

8. Keszthelyi Sz. (2017): A Tesztüzemi Információs Rendszer eredményei 2015. Agrárgazdasági Kutató Intézet. p. 14. ISSN 2063-3149 DOI: 10.7896/ai1792

9. Keszthelyi Sz. - Kis Csatári E. (2018): A Tesztüzemi Információs Rendszer eredményei 2016. Agrárgazdasági Kutató Intézet. Budapest. p. 14. ISSN 2063-3149 DOI: $10.7896 /$ ai1 801

10. Keszthelyi Sz. - Kis Csatári E. (2019): A Tesztüzemi Információs Rendszer eredményei 2017. Agrárgazdasági Kutató Intézet. Budapest. p. 14. ISSN 2063-3149 DOI: 10.7896/ai1902

11. Keszthelyi Sz. - Kis Csatári E. (2020): A Tesztüzemi Információs Rendszer eredményei 2018. Agrárgazdasági Kutató Intézet. Budapest. p. 14. ISSN 2063-3149 DOI: 10.7896/ai2002

12. KSH (2018): Szántóföldi növények, 2017. Statisztikai tükör. 2018. február 9. Központi Statisztikai Hivatal. Budapest. 4 p.

13. KSH (2019): Főbb növénykultúrák terméseredményei, 2018. Statisztikai tükör. 2019. február 15. Központi Statisztikai Hivatal. Budapest. 5 p.

14. KSH (2020a): Helyzetkép a mezőgazdaságról, 2019. Központi Statisztikai Hivatal. Budapest.

Letöltés:

https://www.ksh.hu/docs/hun/xftp/idoszaki/mezo/2019/index.html 
15. KSH (2020b): Központi Statisztikai Hivatal adatbázisa. Letöltés: http://www.ksh.hu/mezogazdasag

16. Nábrádi A. - Pető K. - Balogh V. - Szabó E. (2008): A hatékonyság mérésének módszertana. In: Hatékonyság a mezőgazdaságban (Szerk.: Szücs I. - Farkasné Fekete M.). Agroinform Kiadó és Nyomda. Budapest. p. 23. ISBN 978-963-502-889-4

17. Nemessályi Zs. (2005): Jövedelem, jövedelmezőség, versenyképesség a hatékonyság rendszerében. In: A mezőgazdaság tőkeszükséglete és hatékonysága: Pfau Ernő professzor 70. születésnapja tiszteletére (Szerk.: Jávor A.). Debreceni Agrártudományi Centrum. Debrecen. p. 199. ISBN 963-472-896-0

18. Pechrova M.S. (2015): The profitability and technical efficiency of young farmers supported from Rural Development Programme. 33rd International Conference Mathematical Methods in Economics. 09-11 September 2015. Cheb, Czech Republic, Conference paper. pp. 618-623.

19. Szabó A. (2019): A mezőgazdaság nemzetgazdasági szerepe - Képviselői Információs Szolgálat. 2019/7. InfoTabló. Letöltés: https://www.parlament.hu/documents/

20. 10181/1789589/Infotablo_2019_7_mg_nemzetgazd_szerepe.pdf/9e2176c0-c76f5475-9cb6-b42bbbd75ff1

21. Szőllősi L. - Molnár Sz. (2017): A versenyképesség meghatározó tényezői I. - piaci igények. Baromfiágazat. Vol. 17. No. 3. pp. 4-11.

22. Szőllősi L. - Szücs I. (2015): Az üzleti tervezés alapjai. Debreceni Egyetem. Debrecen. p. 107. ISBN 978-615-80290-7-0

23. TAKARNET (2020): Statisztikai adatok - Hajdúböszörmény. Letöltés: http://www.takarnet.hu/pls/tknet/hivatalok_p.kozseg_adat?kozsegkod=2287

24. Vinogradov Sz. - Takácsné György K. (2019): A szántóföld piaci árát befolyásoló tényezők. Agro Napló. Vol. 23. No. 12. pp. 44-47. 